Published in Research in international business and finance, 2016, which should be cited to refer to this work.

\title{
Determinants of the Capital Adequacy Ratio of Foreign Banks' Subsidiaries: The Role of Interbank Market and Regulation
}

\author{
Mehdi Mili $^{\mathrm{a}}$, Jean-Michel Sahut ${ }^{\mathrm{b}}$, Hatem Trimeche ${ }^{\mathrm{c}}$, Frédéric Teulon ${ }^{\mathrm{d}}$
}

\begin{abstract}
This paper examines the factors influencing the capital adequacy ratio (CAR) of foreign banks. We test whether the CAR of subsidiaries and branches in developed and developing countries depends on the same factors. We use data from 310 subsidiaries and 265 branches to test the impact of the parent banks' fundamentals on subsidiaries' and branches' capital ratios. We also study how the economic condition and regulatory environment in a bank's home country determine foreign banks' CAR. Our results provide strong evidence that the CAR of subsidiaries and branches operating in developing and developed countries do not depend on the same set of explanatory factors. We also find that the regulatory framework of a parent bank's home country affects the capitalization of its foreign subsidiaries in the host countries. Finally, we show that specific variables of the parent bank have a stronger effect for foreign banks highly related to the interbank market.
\end{abstract}

Keywords: capital adequacy ratio, multinational bank, interbank market, regulation, branch, subsidiary

JEL classification codes: F15, F34, G21.

a University of Bahrain, CBA, Bahrain

b IDRAC, France \& HEG Fribourg, University of Applied Sciences Western Switzerland,

c High School of Management of Sousse, Tunisia

d IPAG Business School, Paris, France 


\section{Introduction}

Banks and regulators have adopted international banking regulations based on recommendations of the Basel Committee to promote the soundness of the global banking system (Agarwal and Jacques; 2001). These regulations require that banks properly assess their risks, since a weak banking system threatens the stability of the economy on national and international scales. Generally perceived as a prerequisite for the proper functioning of global banking systems, the regulatory model recommended by the Basel Committee is fundamentally based upon the "paradigm of supervision of bank capital," as proposed by Caprio and Honohan (1999). In this context, the capital adequacy ratio (CAR), one of the principal regulatory tools used to control and scrutinize a bank's financial health, has received particular attention from international regulatory authorities. According to Sinkey (1989), regulators use the CAR as an important measure of the "safety and soundness" of depository institutions because they consider capital a safety margin capable of absorbing potential losses. Several studies have examined the capital structures of banks in several countries in order to identify the determinants of the CAR; most have tried to explain how a bank's financial health affects the CAR's evolution.

This paper represents a major contribution to this recent literature, as we focus on the role of foreign banks' organizational forms in determining CAR levels. Multinational banks operate in host countries in one of two organizational forms: subsidiaries, which are separate entities subject to the regulation of the host country's authorities, or branches, which are regulated by the authorities of the parent bank's country (Fiechter et al.; 2011). We hypothesize that the degree of parent banks' legal responsibility vis-à-vis the liabilities of their branches and subsidiaries has an impact on each form of foreign bank.

There are at least two reasons to justify our hypothesis that parent banks' financial characteristics affect their entities differently. First, the problem of the foreign bank's 
solvency is part of the parent bank's overall risk management (Feria-Dominguez et al., 2015). Thus, the capitalization of the foreign bank is not executed independently in the home country. Second, the global integration of financial systems and efforts to harmonize banking supervision have forced central banks to care about how foreign banks operate in host countries and their capitalization (De Haas and van Lelyveld; 2010). While subsidiaries are separate from their parents (and are regulated by the host country's regulators), branch liabilities are the responsibility of their parent banks (and are regulated mainly by the parent bank's regulators); this can determine the parent banks' risk-taking behavior (Tomšík, 2015). Subsidiaries can be used to take more risks abroad if the parent bank considers the local regulator to be "weaker" and if the regulators do not cooperate. This implies that local regulators in host countries should carefully assess subsidiaries' risks to ensure the stability of their banking sectors.

Our research is based on literature showing that parent banks exert significant influence on the financial fundamentals of their foreign subsidiaries. Dee Haas and Van Lelyveld (2006, 2010) and Martinez Peria et al. (2002) suggested that parent banks support their foreign subsidiaries, especially during crises, allowing them to be resilient under economic shocks. Morgan et al. (2004) developed a theoretical framework explaining how lending by multinational banks' subsidiaries is influenced by the funding strategy of their parent banks; they described the funding mechanism between them using an internal capital market. This evidence concerning parent banks' effect on their foreign entities led us to test how the parent banks affect the level of capitalization of foreign branches and subsidiaries.

The rest of this paper is organized as follows. Section 2 reviews the literature and current theoretical perspectives to explain the determinants of a bank's solvency ratio, while emphasizing the role of the parent bank in its determination. Section 3 presents the study's methodology and section 4 presents the empirical results. Section 5 concludes. 


\section{Literature review and theoretical framework}

The recent trend towards financial liberalization and the increased cross-border activities of several banks are forcing banking supervision to cover all banking transactions worldwide. For multinational banks, control of foreign banks' subsidiaries is exerted by regulatory authorities in both the home and host countries. Multinational banks generally have complex organizations that regulators find challenging. To address this complexity, coordination between the authorities in the country of origin and destination is required. De Haas and van Lelyveld (2010) suggested that regulatory control procedures for foreign subsidiaries should focus on the financial indicators (i.e., solvency, liquidity risk) that depend on the stability of the national and international banking systems.

On a theoretical level, our study is related to the work of Harr and Ronde (2006), who studied the capital regulation of multinational banks. They analyzed cases wherein multinational subsidiaries are subject to two national regulators who strategically determine capital requirements; they concluded that capital requirements may increase when foreign subsidiaries are subject to two regulators. Other studies have focused on the problem of divergent interests and lack of coordination between national regulators (Acharya; 2003, Calzolari and Loranth; 2003, Dalen and Olsen; 2003, Holthausen and Ronde; 2005, Dell'Ariccia and Marquez; 2006, Hoggarth et al.; 2013.).

The organizational form in which a bank chooses to operate in a foreign country determines its regulatory framework in the host country. Cerutti (2007) suggested that the choice of banks to operate as locally chartered and independently capitalized subsidiaries or as branches when abroad mainly depends on the regulatory framework of the host country. Their result emphasizes that the capitalization of a foreign bank should depend on its organizational form. For regulatory authorities, the problem is to define the tools for controlling and scrutinizing a bank's financial health; this generated the concept of "capital adequacy" in the mid-1970s. 
The expansion of lending by banks without a parallel increase in their capital has forced regulators to define several control procedures and issue new reforms in order to avoid insolvency in the banking sector. In the same context (i.e., protection against shocks), capital requirements are the most frequently cited prudential regulation. The importance of regulatory capital in ensuring banking stability has motivated several researchers ${ }^{1}$ to study the determinants of regulatory capital banks. Our investigation of the literature shows that studies on the determinants of banks' CAR have taken two distinct methodological paths.

One focuses on explaining banks' capitalization levels using only financial variables. Ayuso and Saurina (2004) and Demsetz and Strahan (1997) showed that large banks can operate with low levels of capital, indicating that large banks may benefit from diversification and can therefore operate with lower capital ratios. Gropp and Heider (2009) and Kleff and Weber (2008) claimed that the most profitable banks tend to have relatively higher regulatory capital. $\mathrm{Yu}(2000)$ demonstrated that liquidity is positively and significantly related to capital ratio, which implies that banks do not consider liquidity a pure direct substitute for capital; thus, it cannot be used to cover whole portfolio risk.

The second path has attempted to include macroeconomic variables. These studies suggest that the national economic environment affects the solvency of a bank; therefore, it should be considered a fundamental determinant of its CAR. For example, Hortlund (2005) tested the impact of inflation on the capitalization of Swedish banks and demonstrated that inflation and the banks' regulatory capital ratios were inversely related. Williams (1998) studied the impact of macroeconomic variables on CAR; he noted that macroeconomic variables such as inflation, real exchange rate, money supply, political instability, and return on investment are significant determinants of regulatory capital.

\footnotetext{
${ }^{1}$ Agrawal and Jacques (2001), Berger et al. (2008), and Kleff and Weber (2008).
} 
In fact, from this overview of the literature, we note that no studies have examined the determinants of foreign subsidiaries' regulatory capital. Our empirical study examines the determinants of the CAR of foreign banks in order to determine the role of the parent bank therein. We contribute to this line of research by examining how the economic conditions and regulatory environment in the bank's home country help determine the CAR of its foreign entities.

\section{Methodological approach}

Our methodological approach occurs in three parts. First, we test the impact of the fundamental financial variables of the subsidiary and the parent bank and integrate the macroeconomic variables of the subsidiary's host country and the parent bank's home country (Shaw et al.; 2013). Then, we test the impacts of these variables by distinguishing among the effects according to the economic maturity of the host country; this process allows us to consider the impact of the regulatory environment of the parent bank's home country. Finally, we test the role of the interbank market.

Our objective is to examine the determinants of the subsidiary's CAR, our dependent variable. The CAR is defined as the capital of a bank expressed as a percentage of its risk-weighted commitments. The international standard recommends a minimum ratio that ensures the bank can absorb a reasonable level of losses before going into financial distress. The application of these minimum capital ratios protects depositors and promotes the stability and efficiency of the financial system as a whole. Two types of capital ratios have been proposed. The first relates to Tier 1 capital, which must absorb the bank's losses without leading to a cessation of activities. The second is Tier 2 capital, usually subordinated debt, which is intended to absorb losses in the event of liquidation and thus provides depositors a modicum of protection. In this study, we use the CAR formula based on both Tier 1 and Tier 2 capital. According to Buchs 
and Mathisen (2005), these ratios measure the strength of a bank's capital and its ability to cover the risks of its undertakings and protect the interests of its depositors; this could enhance the stability and efficiency of the banking system. Figuet (2003) stated that capital helps to limit bank failures and, consequently, the costs of its rescue and restructuring. Diamond and Rajan (2000) stated that high capital reduces banks' liquidity creation but allows them to be strong and avoid bankruptcy.

In our empirical framework, subsidiaries' risk-adjusted capital (RAC) will be explained by two types of variables: we use the specific financial variables of subsidiaries and parent banks, while also considering the macroeconomics variables concerning the country of origin and the host country. The specific financial variables of subsidiaries and parent banks are described below.

Size. The size of the bank may affect its diversification strategies, risks, and access to capital markets. This is proved by Demsetz and Strahan (1997), who concluded that large banks enjoy better diversification and therefore operate with lower capital ratios. Similarly, Ayuso et al. (2004) showed that large banks have lower capital levels. We use the logarithm of total assets (T_Asset) as a measure of size, and we expect an inverse relationship between size and CAR.

Deposit Ratio. An increase in bank deposits requires regulation to guarantee the rights of depositors and preserve the bank's solvency. The ratio of total deposits to total assets is used to measure the impact of deposits upon capital. According to Kleff and Weber (2008), deposits are generally considered cheaper sources of funds with respect to credit and similar financing instruments, such as bond financing and loan securitization. Following Asarkaya and Özcan (2007), we expect deposits to have a negative effect on the CAR.

Loan Ratio. Increased loans expose a bank to higher risk; therefore, the CAR should increase. According to Mili et al. (2015), higher loan ratios may reduce the bank's liquidity and 
increase the number of defaulters. Mpuga (2002) found a positive relationship between CAR and the share of loans. The loan ratio is measured by total loans to total assets.

Profitability. Most of the literature claims that profitability has a significant effect on the bank's CAR. Brown and Octavia (2010) and Gropp and Heider (2009) concluded that the most profitable banks tend to have lower levels of regulatory capital than less profitable ones. On the basis of these arguments, we expect a negative relationship between the profitability ratios of assets (i.e., return on assets $[\mathrm{ROA}]$ ) and the capitalization of the subsidiary.

Net Interest Margin (NIM). The NIM is a parameter reflecting bank profitability. Moreover, it reflects both the volume and composition of assets and liabilities and influences the bank's risk portfolio. According to Angbazo (1997), adequate NIMs are expected to generate sufficient income to increase capital with increasing exposure to risk. Berger and Herring (1995), Demirgüç-Kunt and Huizinga (1998, 2002) and Lin et al. (2005) found a positive relationship between the NIM and the ratio of equity.

The second group of variables comprises the macroeconomic variables of the parent bank's home country and of the host country in which the foreign subsidiary operates.

GDP growth. In accordance with most studies, such as Ruckes (2004), we expect a negative relationship between credit growth and capital ratios. We assume that bank risk is lower in times of strong economic growth, leading banks to reduce their regulatory capital. Lowgrowth periods increase a bank's financial risk and encourage banks to maintain a high capital ratio.

Real interest rates. Demirgüç-Kunt and Detragiache (1998) showed that higher real interest rates can adversely affect borrowers' repayment capacity, which can negatively affect capital ratios should many borrowers default on their payments. We, therefore, expect a negative relationship between real interest rates and capital ratios. 
Real effective exchange rate. Williams (1998) found that the real effective exchange rate is another important determinant of the CAR. He identified an inverse relationship between the exchange rate and the CAR, implying that an increase in the real exchange rate reduces foreign direct investment and thus reduces the CAR.

To control for the impact of the recent financial crisis on foreign bank capitalization, we use a dummy variable, Crisis, as a control variable; it equals 1 for the period from 2007 to 2010 and 0 otherwise.

Our econometric approach, similar to that used by Allen et al. (2014) and Dee Haas and Van Lelyveld (2010), explains foreign subsidiaries' CAR using the fundamental variables of the subsidiary and its parent bank and the economic variables of the host and home countries. Formally, we consider the following model:

$$
\Delta C A R_{i t}=f\left(\text { Bank }_{i t}, \text { Country }_{i t}, \text { ParentBank }_{i t}, \text { ParentCountry }_{i t}\right)
$$

where $\triangle C A R_{i t}$ is the change in capital adequacy of subsidiary $i$ in year $t, B_{a n k}$ is a matrix of the foreign subsidiary controls of subsidiary $i$, and Country ${ }_{i t}$ is a matrix of the macroeconomic variables of the country where subsidiary $i$ is located. ParentBank $k_{i t}$ is a matrix of the parent bank characteristics of subsidiary $i$ in year $t$, and ParentCountry $y_{i t}$ is a matrix of the macroeconomic variables of the country of the parent bank of subsidiary $i$. We estimate our model using GMM, which corrects for biases associated with endogenous regressors and country-specific heterogeneity (Wilde, 2005).

\section{Empirical results}

\subsection{Data and preliminary statistics}

To determine the factors affecting the regulatory capital of branches and subsidiaries in developed and developing countries, we combine bank-specific financial data with the countries' macroeconomic data. 
Our database consists of 310 subsidiaries of 123 multinational banks. Among the foreign subsidiaries selected, 180 operate in developed countries and 130 in developing countries. ${ }^{2}$ We also select 265 branches of 85 multinational banks, among which 120 operate in developing countries and 145 operate in developing countries. The fundamental variables of the subsidiaries, branches, and parent banks are collected for the period 2000 to 2010 from Bankscope. All variables are expressed in US dollars. To obtain data for the entire study period, we selected the branches and subsidiaries that have been operating for more than 10 years. Macroeconomic data are provided by the International Monetary Fund database and cover the same period.

Table 1 provides a summary of the variables used in our empirical estimation, along with their sources.

\section{Insert Table 1.}

Table 2 presents the summary statistics of the variables for branches and foreign bank subsidiaries. The table shows that subsidiaries differ from branches in terms of financial structure and performance. On average, subsidiaries are larger and more capitalized than branches. This is in line with the results of Cerutti (2013) who support that subsidiaries have typically higher capital, reserve requirements and assets than branches. Both subsidiaries and branches appear more capitalized in developed countries. Subsidiaries seem to have a higher level of risk in terms of loan loss provisions than branches.

Comparing subsidiaries in developed and developing countries, our descriptive statistics are consistent with those of Allen et al. (2014): the subsidiaries in developed countries are more capitalized, probably because developed countries' regulatory requirements are generally

\footnotetext{
${ }^{2}$ We adopt the classification of developing countries used by the International Monetary Fund.
} 
more stringent. Table 2 also shows that multinational banks tend to operate with larger subsidiaries in developed countries, where the banking industry is more competitive. Subsidiaries and branches in developed countries also seem to perform better, since they have a higher ROA and lower loan loss provisions. Islahuzzaman (2014) made the same observation.

\section{Insert Table 2.}

\subsection{A first approach of the CAR}

Table 3 presents the estimation results of model 1. The first specification reports the results of the base model line, where the CAR of the subsidiary or branch is regressed against their specific characteristics and the host countries' macroeconomic variables. For subsidiaries, the coefficient of loan loss provision is positive and statistically significant, suggesting that bad loans increase the subsidiary's risk, which requires greater capitalization. Loan loss provision appears more significant for branches, implying that subsidiaries can be used to take more risk abroad if the parent bank considers the local regulation to be weak or if the regulators do not cooperate.

The coefficients of Loans appear significantly positive in all regression models, but the effect is more significant for subsidiaries, suggesting that subsidiaries are restricted to increasing their capital in accordance with local regulations and that regulatory capital may grow after a period of credit expansion. More loans imply higher engagements, which require higher legal capital to cover risk.

Contrary to Ayuso et al. (2004), who found that larger subsidiaries hold lower levels of capital, we found that subsidiary size has a negative and significant effect on the CAR. Branch size has a negative and insignificant impact on the CAR. This can be explained by the fact that the regulatory capital of the branch management is centralized at the parent bank 
level, as is confirmed by the negative and significant impact of parent bank size on branch CAR.

Among the macroeconomic variables, economic growth and the real interest rates of the host country seem to affect the subsidiaries' capital ratio significantly. The coefficient of GDP growth exhibits a positive and significant sign, a result in line with the findings of Schaeck et al. (2006), who suggested that a high level of economic development requires sophisticated procedures for banking supervision. The GDP growth in local currency has no significant effect on branches' CAR, reflecting the fact that, as the branches' regulation is related to their parent banks, their CAR should depend more on economic growth in the parent's country.

\section{Insert Table 3.}

The coefficients of real interest rate appear significantly negative and have almost the same size for subsidiaries and branches. One possible explanation is that rising real interest rates negatively affect borrowers' ability to repay their loans, which can negatively affect capital ratios if many borrowers default on their payments. This result is well documented in Demirgüç-Kunt and Detragiache (1998).

In models (2) and (4), we expand our baseline model by adding specific variables of the parent bank and macro variables of the home country. The coefficients of the size of the parent banks appear significantly negative for both organizational forms, but the effect appears more important for branches. This finding implies that larger multinational banks are generally more capable of taking advantage of international diversification, allowing their branches to operate with lower capital ratios. This result is in line with the findings of Gropp and Heider (2009) and Shrieves and Dahl (1992), who suggested that large banks benefit from more flexible regulation of their CAR than small banks do. 
The loan loss provision coefficients of parent banks appear significantly positive for the two organizational forms, indicating that deterioration in the quality of the parent banks' loans portfolio increases the distress risk for their subsidiaries and branches.

The branches' CARs depend more on the Net Interest Margin of their parents than on their own Net Interest Margin. This is can be explained by the fact that the branches' regulation depends on the parent bank. This result is consistent with Gropp and Heider (2009) and Kleff and Weber (2008). The parent bank's Net Interest Margin exerts a positive but insignificant impact on the CAR of the subsidiary, indicating that the parent's operating performance does not affect the subsidiary's level of capital. This table also shows that deposits and profitability (ROA) have an insignificant impact on subsidiaries' and branches' CARs.

We capture how the recent financial crisis has affected the foreign subsidiaries' and branches' capitalization with the dummy variable Crisis, which takes a value of 1 for the 2008-2010 period and 0 otherwise.

The results show a positive impact of the crisis, which appears more significant for subsidiaries. This result implies that the pressures of regulatory capital requirements exerted by local regulatory authorities on foreign subsidiaries in times of crisis are stronger than the pressures exerted by the parent countries' authorities on bank branches.

\subsection{The CAR for developed and developing countries}

We examine the impact of the regulatory environment of the parent bank's home country on the capitalization of its foreign subsidiaries and branches by dividing the sample into two groups: foreign organizations operating in developed countries and foreign organizations operating in developing countries.

In addition, each Capital Regulation Index of the host and home countries are included as an explanatory variable. This index, developed by the World Bank, surveys bank regulation 
(2003, 2007, and 2011) and combines two dimensions. First, it reflects the overall capital stringency in the banking sector, demonstrating whether the capital requirement reflects certain risk aspects and deducts certain market value losses from capital before minimum capital adequacy is determined. Second, this index values the initial capital stringency, which indicates whether funds may be used to capitalize a bank initially and whether they are used officially. The Capital Regulation Index ranges from 0 to 10 , with a high value indicating greater stringency. We expect that banking regulations imposed in the home country have an impact on the capitalization of subsidiaries in foreign countries.

The results are reported in Table 4, which shows that the CARs of foreign subsidiaries and branches in developing and developed countries do not depend on the same set of factors. The capital ratio of subsidiaries in developing countries, in particular, depends more on specific bank and macroeconomics variables in the host country. However, in developed countries, the parent bank's fundamentals significantly determine the CAR level. These results show that banking regulation in developed countries is more severe than in developing countries and considers the financial health of the parent bank and the home country.

On the contrary, branches' regulatory capital in developing countries appears to be affected more by the economic conditions in the parent countries than by economic growth in the host countries. The specific fundamentals of the parent banks also have more impact on branches' CAR in developing countries than in developed countries, implying that weak local regulation in developing countries encourages parent banks to operate with lower regulatory capital in host countries.

Subsidiary loans have a lower but significant impact on their CARs in developing countries, indicating that subsidiaries can be used to take more risk in host countries if the parent bank finds that the local regulation is very weak and if the regulators do not cooperate. 
The table 4 shows that large parent banks with strong ROA are more likely to reduce the CAR of their foreign subsidiaries operating in developed countries. These variables (i.e., parent bank's size and ROA) appear insignificant for subsidiaries operating in developing countries. The parent bank's loan loss provisions seem to affect its foreign subsidiaries operating in both developed and developing countries but with a higher impact on those in developed countries. The coefficients of loan loss provisions and ROA of the foreign subsidiaries are positively significant in developing countries but insignificant in developed ones. Two possible explanations of this result may be put forward. First, foreign subsidiaries in developing countries increase their regulatory capital as their portfolio risk increases, hence, affecting the quality of their loans. Second, profitable banks increase their capital through retained earnings.

The effects of the host country's macroeconomic conditions on the subsidiary are more pronounced in developing countries owing to the significant coefficient of GDP growth and real interest rates. In developed countries, GDP growth appears significant only at the $10 \%$ level.

For branches, we find that GDP growth in the parent country has a significant impact only on branch capitalization operating in developing countries, showing that branch risk in developing countries is regulated primarily by the parent bank.

The table 4 also shows that the parent bank's fragility negatively affects the CAR of its foreign subsidiaries in developed countries. This is seen in the coefficient of the Net Interest Margin of the parent bank, which appears to be significant for developed host countries and insignificant for developing ones. Nevertheless, other bank characteristics do not have any impact on either group of foreign subsidiaries.

In addition, the size of the parent bank has a positive and significant impact on the capitalization of its branches in developed countries, which could indicate that large 
multinational banks tend to operate higher capitalized branches in developed countries, where the banking sector is highly competitive.

\section{Insert Table 4.}

The coefficient of the dummy variable, Crisis, seems to be significantly positive only for foreign subsidiaries operating in developed countries, showing that the capitalization of subsidiaries in these countries is strongly linked to the economic situation of the host country. Given the integration of financial markets and banking sectors, regulatory authorities in developed countries require strong capitalization in the foreign subsidiaries operating in their markets. By contrast, the effect of the financial crisis on branches' capitalization appears significantly positive in both developed and developing countries.

A particularly interesting result is seen in the regulatory index of both organizational forms. The home country regulatory index seems to affect the two groups of subsidiaries differently. Parent banks with stronger local banking regulations reduce the capitalization of their foreign subsidiaries operating in developing countries if they have the option to do so. However, in developed countries, where banking regulation is usually more rigid, subsidiaries have to operate with higher capitalization. The regulatory index has almost the same positive impact on branches in developed and developing countries. The power and responsibilities of supervising authorities in the host countries are reduced for bank branches. Reducing responsibility means increasing risk, but this can provide two main advantages: first, the host authority is more vulnerable to contagion from foreign banking groups; second, the costs of regulatory failure are assumed by the country of origin rather than by themselves. The regulation indexes of the host countries positively affect the subsidiaries' and branches' capitalization in developed and developing countries. 


\subsection{CAR and interbank dependency}

Finally, we divide our sample into two subsamples in order to explore the effect of the integration of the subsidiaries' capitalization with the interbank market and to adjust for market discipline. The interbank ratio is measured by interbank lending to borrowing.

The first subsample consists of banks with an interbank rate below one and is considered highly interbank-borrowing related; this means that the first group of foreign subsidiaries finances their foreign loans from the interbank market, which is a risky strategy for many banks in periods such as the recent crisis. However, an interbank ratio above one means that the foreign subsidiary is well positioned in the interbank market and so has not been forced to take loans during the recent crisis. This reflects the assertion that other banks have the ability to monitor their peers in the interbank market (Nier and Baumann, 2006), and also have the incentive to do so because interbank deposits are not typically covered by deposit protection schemes.

We expect that the integration of foreign subsidiaries and branches in the interbank market has an impact on its regulatory capitalization ratio. The results of these estimations are presented in Table 5.

Overall, the results show that the capitalization of subsidiaries highly related to the interbank market depends more on the subsidiaries' fundamentals, while the CARs of branches highly related to the interbank market depend more on the parent banks' fundamentals.

The coefficient the subsidiaries' loan loss provision seems positively significant for those that are heavily related to the interbank market, showing that the financial fragility of the subsidiary leads it to increase its CAR. Loan loss provision has a significant effect on branches strongly and weakly related to the interbank market but the effect is more significant for more related interbank branches. 
The size variable seems to be negatively significant only for foreign subsidiaries that are highly related to the interbank market, implying that larger subsidiaries that are highly integrated in the banking sector in the host country can diversify their risk portfolio, allowing them to reduce their CAR. The profitability of the subsidiary has a significant impact on both groups, an effect that is stronger for subsidiaries more related to the interbank market.

Regarding the subsample of foreign subsidiaries slightly related to the interbank market, the loan loss and net interest margin of their parent banks have significant impacts on their capitalization, perhaps because the subsidiaries with a weak position in the interbank market are not overly controlled in the host country markets and their level of regulatory capital depends on the loan quality and operational performance of their parent bank.

\section{Insert Table 5.}

We also find that the macroeconomic variables of the host country play an important role in the capitalization of the subsidiaries that are highly related to the interbank market. We find that the CAR depends significantly on GDP growth in the host country, implying that foreign subsidiaries operating in the interbank market are dependent on the monetary and financial conditions in their host countries. However, the macroeconomic variables are insignificant for foreign subsidiaries with low dependence on the interbank market.

The capitalization of branches heavily related to the interbank market is significantly affected by GDP growth in the parent country, while the capitalization of branches weakly related to the interbank market depends significantly only on economic conditions in the host countries. This implies that the interbank market allows branches to raise stable resources from host countries, which reduces their risk. 


\section{Conclusion}

The study investigates the determinants of the CAR of foreign subsidiaries. We provide strong evidence that the CAR of subsidiaries and branches operating in developed and developing countries do not depend on the same explanatory factors. We show that the fragility of parent banks affects the capitalization of their foreign subsidiaries; this is important, especially when the foreign subsidiary operates in a developed country. This result emphasizes the fundamental role played by multinational banks in the stability of the global banking system. In developing countries, branch regulatory capital is shown to be more affected by the economic conditions in the parent country than by economic growth in the host country. This can be explained by the fact that the management of the branches' regulatory capital is in the hands of their parent banks.

In addition, our empirical findings show that the regulatory framework of a parent bank's home country affects the capitalization of its foreign subsidiaries in the host country. Another important finding relates to the role of the interbank market in determining the subsidiaries' CAR. We conclude that the parent bank's effect is stronger for foreign banks highly related to the interbank market.

Our results are important owing to the apparently increased opening of the banking sector in developing countries to multinational banks. We find that the monetary authorities in developing countries, especially central banks seeking to stabilize their banking sectors, should impose more stringent regulations on foreign subsidiaries, as this could enhance their financial risk conditions. 


\section{References}

Acharya, V., 2003, "Is the International Convergence of Capital Adequacy Regulation desirable?", Journal of Finance, 58(6), 2745-2781.

Agarwal, R, and Jacques, K.T., 2001, "The impact of FDICIA and prompt corrective action on bank capital and risk: Estimates using a simultaneous equations model", Journal of Banking and Finance, 15, 847-874.

Allen, F., Hryckiewicz, A., Kowalewski O., and Tumer-Alkan G., 2014, “Transmission of Bank Liquidity Shocks in Loan and Deposit Markets: The Role of Interbank Borrowing and Market Monitoring”, Journal of Financial Stability, 15, December, 112-126.

Angbazo, L., 1997, “Commercial bank net interest margins, default risk, interest-rate risk, and off-balance sheet banking”, Journal of Banking and Finance, 21(1), 55-87.

Asarkaya, Y., and Ozcan, S., 2007, "Determinants of capital structure in financial institutions: The case of Turkey", Journal of BRSA and Financial Markets, 1(1), 91-109.

Ayuso, J., Perez, D., and Saurina, J., 2004, "Are capital buffers procyclical? Evidence from Spanish panel data", Journal of Financial Intermediation, 13, 249-264.

Buchs, T., and Mathisen, J., 2005, "Competition and Efficiency in Banking: Behavioral Evidence from Ghana', IMF Working Paper, WP/05/17, African Department.

Berger, A.N., and Herring, R.J., 1995, "The role of capital in financial institutions", Journal of Banking and Finance, 19(3), 393-430.

Berger, N., De Young, R., Mark J., Lee, D., and Aozde, O., 2008, "How do large banking manage their capital ratios", Journal of Financial Research, 34(2-3), 123-149.

Brown, R., and Octavia, M., 2010, "Determinants of bank capital structure in developing countries: regulatory capital requirement versus the standard determinants of capital structure", Journal of Emerging Markets, 15(1), 50-62.

Calzolari, G., and Loranth, G., 2003, "On the Regulation of Multinational Banks", in Antitrust, Regulation and Competition: Theory and Practice, L. Lambertini Ed., Palgrave Macmillan, 265-290.

Caprio, G., and Honohan, P., 1999, "Beyond capital ideals: restoring banking stability," Policy Research Working Paper, World Bank, n²235, World Bank, Washington, DC.

Cerutti, E., 2013, 'Banks' Foreign Credit Exposures and Borrowers' Rollover Risks Measurement, Evolution and Determinants", IMF Working Paper No. 13/9.

Cerutti, E., Dell'Ariccia, G., and Martinez Peria, M., 2007, "How Banks Go Abroad: Branches or Subsidiaries", Journal of Banking and Finance, 31(6), 1669-1692.

Dalen, D.M., and Olsen, T., 2003, "Strategic regulation of a multi-national banking industry", mimeo, Norwegian School of Economics and Business Administration.

Dell'Ariccia, G., and Marquez, R., 2006, "Competition among Regulators and Credit Market Integration", Journal of Financial Economics, 79(2), 401-430.

De Haas, R., and van Lelyveld, I., 2006, "Foreign Banks and Credit Stability in Central and Eastern Europe. A Panel Data Analysis”, Journal of Banking and Finance, 30(7), 19271952. 
De Haas, R., and van Lelyveld, I., 2010, "Internal Capital Markets and Lending by Multinational Bank Subsidiaries", Journal of Financial Intermediation, 19(1), 1-25.

Demirgüç-Kunt, A., and Detragiache, E., 1998, "The determinants of banking crises in developing and developed countries", IMF Staff Papers, 45 (1), 81-109.

Demirgüç-Kunt, A., and Detragiache, E., 2002, "Does deposit insurance increase banking system stability? An empirical investigation", Journal of Monetary Economics, 49(7), 1373-1406.

Demsetz, R.S., and Strahan, P.E., 1997, "Diversification, size, and risk at U.S. bank holding companies", Journal of Money, Credit, and Banking, 29(3), 300-313.

Diamond, D.W., and Rajan, R.G., 2000, “A theory of bank capital”, CRSP working papers 363, Center for Research in Security Prices, The Journal of Finance, 55(6), 2431-2465.

Feria-Dominguez, J.M., Jimenez-Rodriguez, E.; Sholarin, O., 2015, "Tackling the overdispersion of operational risk: Implications on capital adequacy requirements". North American Journal of Economics and Finance, 31, 206-221.

Fiechter, J., Otker-Robe, I., Ilyna, A., Hsu, M., Santos, A., and Surti, J., 2011, "Subsidiaries or branches: Does one size fit all?", IMF Staff Discussion Note, March.

Figuet, J.M., 2003, "Le traitement du risque de crédit dans l'accord de Bâle II: Une évaluation", Revue d'Économie Financière, n71, 271-293.

Gropp, R., and Heider, F., 2009, "The Determinants of Bank Capital Structure", European Central Bank Working Paper Series n 1096, September.

Harr, T., and Rønde, T., 2006, "Branch or Subsidiary? Capital Regulation of Multinational Banks", mimeo, University of Copenhagen.

Hoggarth G., Hooley, J., Korniyenko, Y. 2013, "Which way do foreign branches sway? Evidence from the recent UK domestic credit cycle", Bank of England Financial Stability Paper No. 22.

Holthausen, C., and Rønde, T. 2005, "Cooperation in international banking supervision: a political economy approach", mimeo, University of Copenhagen and CEPR Discussion Paper No. 4990.

Hortlund, P., 2005, "Do Inflation and High Taxes Increase Bank Leverage?", Stockholm School of Economics, Working Paper Series in Economics and Finance, No 612.

Islahuzzaman, M., 2014, "The correlation between banking ratio, return on asset, capital adequacy ratio with going concern in audit opinion", Journal of Global Business \& Economics, 8(1), 1-16.

Kleff, V., and Weber, M., 2008, "How Do Banks Determine Capital? Evidence from Germany”, German Economic Review, 9(8), 354-372 .

Martinez Peria, M., Powell, A., and Vladkova Hollar, I., 2002, "Banking on Foreigners: The Behavior of International Bank Lending to Latin America, 1985-2000", World Bank Working Paper No. 2893, World Bank, Washington, DC.

Mili, M., Sahut, JM., Trimeche, E., 2015, "The role of Islamic banks subsidiaries in the transmission of liquidity shocks across countries", Journal of Economic Issues, 49(1), 197-225.

Morgan, D., Rime, B., and Strahan, P.E., 2004, "Bank integration and state business volatility", Quarterly Journal of Economic, 119, 1555-85. 
Mpuga, P., 2002. "The 1998-99 banking crisis in Uganda: What was the role of the new capital requirements?", Journal of Financial Regulation and Compliance, 10(3), 224242.

Nier, E., and Baumann, U., 2006, "Market discipline, disclosure and moral hazard in banking", Journal of Financial Intermediation, 15(3), 332-361.

Ruckes, M., 2004, "Bank competition and credit standards", Review of Financial Studies, Vol. 17(4), 1073-1102.

Schaeck, K., Cihak, M., and Wolfe, S., 2006, "Are more competitive banking systems more stable?", IMF Working Paper, WP/06/143, Washington, D.C.

Shaw, M-f., Chang J-j., Chan, H-j., 2013, "Capital adequacy and the bank lending channel: Macroeconomic implications", Journal of Macroeconomics, 36, 121-137.

Shrieves, R.E., and Dahl, D., 1992, "The relationship between risk and capital in commercial banks", Journal of Banking and Finance, 16(2), 439-457.

Sinkey, J.F., 1989, Commercial Bank Financial Management in the Financial Services Industry, Third Edition, U.S.A.: MacMillan Publishing Company.

Tomšík, V., 2015 “International Banks’ Business Models: Branches vs Sabsidiaries” Bank for International Settlements, Basel February 2015.

Wilde, J., 2005, "A note on GMM-estimation of probit models with endogenous regressors", IWH-Diskussionspapiere, 4/2005.

Williams, B., 1998, "A pooled study of the profits and size of foreign banks in Australia", Journal of Multinational Financial Management, 8, 211-231.

Yu, H.C., 2000, "Banks' capital structure and the liquid asset-policy implication of Taiwan", Pacific Economic Review, 5(1), 109-114. 
Table 1. Variable definitions

\begin{tabular}{|c|c|c|c|}
\hline & Variable & Description & Source \\
\hline \multirow[t]{7}{*}{ Specific variables } & CAR & Capital adequacy ratio & Bankscope \\
\hline & Size & $\begin{array}{l}\text { The logarithm of total assets of foreign } \\
\text { subsidiaries and parent banks. }\end{array}$ & Bankscope \\
\hline & Deposits & $\begin{array}{l}\text { Total deposit divided by the total assets of } \\
\text { subsidiary or parent bank deposits. }\end{array}$ & Bankscope \\
\hline & Loans & The ratio of total loans to total assets & Bankscope \\
\hline & Loan loss provision & Ratio of loan loss provisions to net loans & Bankscope \\
\hline & ROA & Return on Asset & Bankscope \\
\hline & NIM & Net Interest Margin & Bankscope \\
\hline \multirow[t]{4}{*}{ Macro-variables } & GDP & Yearly change in GDP growth & $\begin{array}{l}\text { World Bank } \\
\text { Development Indicators }\end{array}$ \\
\hline & Interest rate & $\begin{array}{l}\text { Real interest rate is the lending interest rate } \\
\text { adjusted for inflation as measured by the GDP } \\
\text { deflator. }\end{array}$ & $\begin{array}{l}\text { World Bank } \\
\text { Development Indicators }\end{array}$ \\
\hline & Exchange rate & Exchange rate from local currency to USD & $\begin{array}{l}\text { World Bank } \\
\text { Development Indicators }\end{array}$ \\
\hline & Crisis & $\begin{array}{l}\text { Dummy variable equal to } 1 \text { if the year } 2007 \text { or } \\
2008 \text { and } 0 \text { if not. }\end{array}$ & Authors construction \\
\hline
\end{tabular}

Table 2. Summary statistics of financial fundamentals of multinational parent banks and foreign subsidiaries

\begin{tabular}{|l|r|r|r|r|r|r|r|r|}
\hline & \multicolumn{7}{|c|}{ Subsidiaries } \\
\hline & \multicolumn{2}{|c|}{ All Subsidiaries } & & \multicolumn{2}{c|}{ Developed } & \multicolumn{2}{c|}{ Developing } \\
\hline & Mean & \multicolumn{1}{|c|}{ Std. Dev. } & & Mean & Std. Dev. & & Mean & Std. Dev. \\
\hline CAR & 12.423 & 3.739 & & 13.847 & 1.782 & & 11.753 & 4.742 \\
\hline Size & 9.853 & 1.623 & & 11.901 & 1.848 & 9.042 & 1.928 \\
\hline Deposits & 0.757 & 9.301 & & 0.886 & 1.219 & & 0.642 & 19.592 \\
\hline Loans ratio & 0.785 & 1.684 & & 0.680 & 0.389 & & 0.881 & 8.929 \\
\hline NIM & 0.051 & 0.984 & & 0.052 & 0.824 & & 0.049 & 1.946 \\
\hline Loan_loss_Prov & 9.968 & 1.390 & & 11.908 & 1.642 & & 14.610 & 2.058 \\
\hline ROA & 0.254 & 2.835 & & 0.292 & 2.320 & & 0.198 & 2.598 \\
\hline & & & & Branches & & & \\
\hline & All Branches & & & Developed & & & Developing \\
\hline & Mean & Std. Dev. & & Mean & Std. Dev. & & Mean & Std. Dev. \\
\hline CAR & 9.829 & 3.125 & & 11.526 & 1.488 & & 9.189 & 2.184 \\
\hline Size & 6.921 & 1.629 & & 9.481 & 1.299 & & 4.864 & 1.146 \\
\hline Deposits & 0.659 & 6.962 & & 0.992 & 5.215 & & 0.588 & 2.559 \\
\hline Loans ratio & 0.481 & 1.519 & & 0.891 & 0.856 & & 0.616 & 1.929 \\
\hline NIM & 0.088 & 0.692 & & 0.052 & 0.984 & & 0.028 & 1.816 \\
\hline Loan_loss_Prov & 6.429 & 1.261 & & 8.865 & 0.219 & & 5.911 & 1.929 \\
\hline ROA & 0.298 & 2.690 & & 0.492 & 1.325 & & 0.266 & 1.225 \\
\hline
\end{tabular}


Table 3. Capital Adequacy Ratio (CAR) estimations

\begin{tabular}{|c|c|c|c|c|}
\hline & \multicolumn{2}{|c|}{ Subsidiaries } & \multicolumn{2}{|c|}{ Branches } \\
\hline & Model (1) & Model (2) & Model (8) & Model (4) \\
\hline \multicolumn{5}{|c|}{ specific characteristics } \\
\hline \multirow[t]{2}{*}{ Size } & $-0.982 *$ & $-0.911 * * *$ & -0.284 & -0.0886 \\
\hline & $(1.924)$ & $(2.986)$ & $(1.846)$ & $(0.929)$ \\
\hline \multirow[t]{2}{*}{ Deposits } & 0.0811 & -0.914 & 0.041 & -0.168 \\
\hline & $(0.129)$ & $(0.199)$ & $(0.461)$ & $(0.191)$ \\
\hline \multirow[t]{2}{*}{ Loan_loss_Prov } & $0.286^{*}$ & $0.148 * * *$ & $0.498 * * *$ & $0.985 * * *$ \\
\hline & $(1.921)$ & $(2.894)$ & $(4.491)$ & $(9.869)$ \\
\hline \multirow[t]{2}{*}{ Loans } & $0.684 * * *$ & $0.696 * * *$ & $0.852 * *$ & $0.829 * *$ \\
\hline & $(4.816)$ & $(6.14)$ & $(2.568)$ & $(2.145)$ \\
\hline \multirow[t]{2}{*}{$\mathrm{ROA}$} & 1.899 & 0.86 & 1.852 & 0.259 \\
\hline & $(0.881)$ & $(0.819)$ & $(0.698)$ & $(0.491)$ \\
\hline \multirow[t]{2}{*}{ NIM } & 0.081 & 0.429 & $0.486^{*}$ & $0.849^{*}$ \\
\hline & $(0.826)$ & $(0.849)$ & $(1.888)$ & $(1.668)$ \\
\hline \multicolumn{5}{|c|}{ Host country variables } \\
\hline \multirow[t]{2}{*}{ GPD growth } & $1.429 * *$ & $1.984 * * *$ & 0.854 & 1.248 \\
\hline & $(2.248)$ & $(4.891)$ & $(1.459)$ & $(0.589)$ \\
\hline \multirow[t]{2}{*}{ Interest rate } & $-0.828 * *$ & $0.514 * * *$ & $0.808 * * *$ & $0.209 * *$ \\
\hline & $(2.561)$ & $(8.104)$ & $(4.958)$ & $(2.186)$ \\
\hline \multirow[t]{2}{*}{ Exchange rate } & 0.929 & 0.964 & 0.845 & 0.994 \\
\hline & $(0.826)$ & $(0.898)$ & $(0.852)$ & $(0.246)$ \\
\hline \multicolumn{5}{|c|}{ Parent bank characteristics } \\
\hline \multirow[t]{2}{*}{ Size } & & $-1.648 * * *$ & & $-4.291 * * *$ \\
\hline & & $(2.858)$ & & $(8.962)$ \\
\hline \multirow[t]{2}{*}{ Deposits } & & 0.886 & & 0.598 \\
\hline & & $(0.091)$ & & $(0.542)$ \\
\hline \multirow[t]{2}{*}{ Loan_loss_Prov } & & $0.299 * * *$ & & $0.868 * * *$ \\
\hline & & $(2.811)$ & & $(8.558)$ \\
\hline \multirow[t]{2}{*}{ Loans } & & -0.964 & & -0.898 \\
\hline & & $(0.99)$ & & $(0.241)$ \\
\hline \multirow[t]{2}{*}{ ROA } & & -0.119 & & -0.486 \\
\hline & & $(0.941)$ & & $(0.869)$ \\
\hline \multirow[t]{2}{*}{$\mathrm{NIM}$} & & 0.841 & & $0.652 * *$ \\
\hline & & $(0.849)$ & & $(2.482)$ \\
\hline \multicolumn{5}{|c|}{ Home Country variables } \\
\hline \multirow[t]{2}{*}{ GDP Growth } & & $8.848 * * *$ & & $4.986 * * *$ \\
\hline & & $(8.141)$ & & $(4.826)$ \\
\hline \multirow[t]{2}{*}{ Crisis } & & $1.148^{* * *}$ & & $1.825 * * *$ \\
\hline & & $(4.848)$ & & $(8.845)$ \\
\hline \multirow[t]{2}{*}{ Constant } & $18.819 * * *$ & $9.894 * * *$ & $14.499 * * *$ & $2.548^{*}$ \\
\hline & $(4.816)$ & $(8.054)$ & $(2.416)$ & $(1.928)$ \\
\hline R-squared & 0.3861 & 0.4162 & 0.3652 & 0.3955 \\
\hline
\end{tabular}

Note. The table reports the estimation results of $(\triangle C A R)$. The dependent variable is the change in capital adequacy ratio of foreign subsidiaries or branches. Size is the logarithm of total assets of foreign subsidiaries and parent banks. Deposits is the total deposit to total assets of subsidiary or parent bank deposits. Loans is the ratio of total loans to total assets. Loan loss provision is the ratio of loan loss provisions to net loans. ROA is the Return on Asset. NIM is the Net Interest Margin. GDP is the yearly change in GDP growth. Real interest rate is the lending interest rate adjusted for inflation as measured by the GDP deflator. Exchange rate is the exchange rate from local currency to USD. Crisis is a dummy variable that equals 1 if the year 2009 or 2008 and 0 if not. T-student statistics are reported between parentheses. ${ }^{* * * * *}$, * denote significance at the $1 \%, 5 \%$ and $10 \%$ levels, respectively. 
Table 4. The CAR for developed and developing countries

\begin{tabular}{|c|c|c|c|c|}
\hline & \multicolumn{2}{|c|}{ Subsidiaries } & \multicolumn{2}{|c|}{ Branches } \\
\hline & developed & developing & developed & developing \\
\hline \multicolumn{5}{|c|}{ Subsidiary characteristics } \\
\hline \multirow[t]{2}{*}{ Size } & $-0.251 * * *$ & $-1.898 * * *$ & -0.895 & $-0.518 *$ \\
\hline & $(4.258)$ & $(8.295)$ & $(0.982)$ & $(1.815)$ \\
\hline \multirow[t]{2}{*}{ Deposits } & -0.858 & $0.285^{* *}$ & -1.282 & 1.812 \\
\hline & (1.098) & $(2.265)$ & (1.558) & $(1.602)$ \\
\hline \multirow[t]{2}{*}{ Loan_loss_Prov } & 0.288 & $0.649 * * *$ & $1.558 * * *$ & $1.899^{* * *}$ \\
\hline & $(0.691)$ & $(2.895)$ & $(8.198)$ & $(2.815)$ \\
\hline \multirow[t]{2}{*}{ Loans } & $0.882 * * *$ & $0.151^{*}$ & 0.215 & $0.585^{* *}$ \\
\hline & $(8.990)$ & $(1.822)$ & (1.282) & $(1.985)$ \\
\hline \multirow[t]{2}{*}{ ROA } & 0.265 & $0.519 *$ & $0.452 *$ & $0.255^{*}$ \\
\hline & $(0.060)$ & $(1.859)$ & $(1.858)$ & $(1.841)$ \\
\hline \multirow[t]{2}{*}{ NIM } & 0.892 & 0.899 & $1.255^{*}$ & 8.859 \\
\hline & $(0.928)$ & $(1.285)$ & $(1.885)$ & $(0.852)$ \\
\hline \multicolumn{5}{|c|}{ Host country variables } \\
\hline \multirow{2}{*}{ GPD growth } & $0.281 *$ & $0.522 * * *$ & 0.196 & 5.598* \\
\hline & $(1.995)$ & $(6.215)$ & $(0.081)$ & $(1.958)$ \\
\hline \multirow[t]{2}{*}{ Interest rate } & 1.289 & $2.282^{* *}$ & $0.588^{*}$ & $0.885^{*}$ \\
\hline & $(1.158)$ & $(1.988)$ & (1.688) & $(1.892)$ \\
\hline \multirow[t]{2}{*}{ Exchange rate } & 2.068 & 1.295 & 5.285 & 1.825 \\
\hline & $(0.528)$ & $(0.289)$ & $(0.299)$ & $(0.098)$ \\
\hline \multirow[t]{2}{*}{ Regulation Index } & $0.868 * *$ & $0.489 * * *$ & $0.890 * * *$ & $8.892 * * *$ \\
\hline & $(2.088)$ & $(4.291)$ & $(8.942)$ & $(2.88)$ \\
\hline \multicolumn{5}{|c|}{ Parent bank characteristics } \\
\hline \multirow[t]{2}{*}{ Size } & $-0.288 * * *$ & -0.929 & $0.585^{*}$ & $-0.285^{*}$ \\
\hline & $(8.128)$ & (1.484) & $(1.888)$ & (1.958) \\
\hline \multirow[t]{2}{*}{ Deposits } & 0.085 & 0.926 & 0.582 & $0.889 *$ \\
\hline & $(1.559)$ & $(1.282)$ & $(1.041)$ & (1.908) \\
\hline \multirow[t]{2}{*}{ Loan_loss_Prov } & $0.851 * * *$ & $0.282 *$ & 0.205 & $0.598 * * *$ \\
\hline & $(8.291)$ & $(1.925)$ & $(1.501)$ & $(5.940)$ \\
\hline \multirow[t]{2}{*}{ Loans } & 0.288 & $0.289 *$ & $0.858 *$ & $0.285^{* * *}$ \\
\hline & $(1.288)$ & $(1.848)$ & $(1.885)$ & $(2.856)$ \\
\hline \multirow[t]{2}{*}{$\mathrm{ROA}$} & $-1.819^{*}$ & -1.228 & -1.858 & $-1.589 * * *$ \\
\hline & $(1.826)$ & $(0.009)$ & $(0.958)$ & $(8.888)$ \\
\hline \multirow[t]{2}{*}{ NIM } & $2.958^{*}$ & 0.894 & $0.944 * * *$ & 0.252 \\
\hline & $(1.842)$ & $(1.089)$ & $(2.821)$ & $(1.249)$ \\
\hline \multicolumn{5}{|c|}{ Country of origin variables } \\
\hline \multirow[t]{2}{*}{ GDP Growth } & -1.952 & -1.880 & -1.859 & $-1.892 * * *$ \\
\hline & $(0.825)$ & $(0.185)$ & $(1.028)$ & $(2.890)$ \\
\hline Crisis & $2.895 * *$ & 0.588 & $1.226^{* * *}$ & $1.859^{* * *}$ \\
\hline & $(1.988)$ & $(0.052)$ & $(2.988)$ & $(5.885)$ \\
\hline Regulation Index & $0.295 * *$ & $-0.188 * * *$ & $0.582 * * *$ & $0.481 * * *$ \\
\hline & $(2.158)$ & $(4.289)$ & $(5.980)$ & $(2.881)$ \\
\hline Constant & $0.482 * * *$ & $0.652 * * *$ & $0.514 *$ & $0.968 * * *$ \\
\hline & $(5.292)$ & $(8.518)$ & $(1.869)$ & $(2.528)$ \\
\hline R-squared & 0.3628 & 0.3775 & 0.4281 & 0.4302 \\
\hline
\end{tabular}

Note. The table reports the estimation results of $(\triangle C A R)$.. The dependent variable is the change in capital adequacy ratio of foreign subsidiaries and branches. Size is the logarithm of total assets of foreign subsidiaries and parent banks. Deposits is the total deposit to total assets of subsidiary or parent bank deposits. Loans is the ratio of total loans to total assets. Loan loss provision is the ratio of loan loss provisions to net loans. ROA is the Return on Asset. NIM is the Net Interest Margin. GDP is the Yearly change in GDP growth. Real interest rate is the lending interest rate adjusted for inflation as measured by the GDP deflator. Exchange rate is the exchange rate from Local currency to USD. Regulation Indexes the Capital Regulation Index of home country as an additional explanatory variable. This index was developed by the World Bank surveys on bank regulation (2008, 2009 and 2011). Crisis is a dummy variable that equals 1 if the year 2009 or 2008 and 0 if not. T-student statistics are reported between parentheses. ${ }^{* * *}, * *, *$ denote significance at the $1 \%, 5 \%$ and $10 \%$ levels, respectively. 
Table 5. CAR and interbank dependency

\begin{tabular}{|c|c|c|c|c|}
\hline & \multicolumn{2}{|c|}{ Subsidiaries } & \multicolumn{2}{|c|}{ Branches } \\
\hline & Interbank $<1$ & Interbank $>1$ & Interbank $<1$ & Interbank $>1$ \\
\hline \multicolumn{5}{|c|}{ Subsidiary characteristics } \\
\hline \multirow[t]{2}{*}{ Size } & $-0.081 * * *$ & $-0.861 *$ & $-5.08 * * *$ & $-8.586 * * *$ \\
\hline & $(5.060)$ & $(1.856)$ & $(8.586)$ & $(8.088)$ \\
\hline \multirow[t]{2}{*}{ Dep_Total_asset } & -0.155 & 0.250 & -0.581 & $.68 * * *$ \\
\hline & $(0.0066)$ & $(0.049)$ & $(0.556)$ & $(5.165)$ \\
\hline \multirow[t]{2}{*}{ Loan_loss_Prov } & $5.85 * * *$ & 0.06 & $0.594 * * *$ & $0.881^{*}$ \\
\hline & $(6.66)$ & $(0.081)$ & $(8.05)$ & $(1.885)$ \\
\hline \multirow[t]{2}{*}{ Loan ratio } & 0.506 & 0.55 & -0.565 & -0.55 \\
\hline & $(0.156)$ & $(0.898)$ & $(0.86)$ & $(0.915)$ \\
\hline \multirow[t]{2}{*}{$\mathrm{ROA}$} & $-0.515 * * *$ & $-8.85 * * *$ & $8.06^{*}$ & 0.868 \\
\hline & $(15.15)$ & $(18.655)$ & $(.551)$ & $(0.6189)$ \\
\hline \multirow[t]{2}{*}{ Dep_Total_asset } & -1.508 & 6.120 & -0.920 & 0.285 \\
\hline & $(0.865)$ & $(0.655)$ & $(.866)$ & $(0.565)$ \\
\hline \multirow[t]{2}{*}{ NIM } & 0.899 & -0.648 & 0.585 & 5.068 \\
\hline & $(0.60)$ & $(0.65)$ & $(0.555)$ & $(.556)$ \\
\hline \multicolumn{5}{|c|}{ Host country variables } \\
\hline \multirow[t]{2}{*}{ GPD growth } & -0.065 & -0.55 & $-1.55 * * *$ & $-0.86 * * *$ \\
\hline & $(1.608)$ & $(0.086)$ & $(5.005)$ & $(6.588)$ \\
\hline \multirow{2}{*}{ Interest rate } & -0.056 & 0.185 & -0.058 & -5.565 \\
\hline & $(0.488)$ & $(1.066)$ & $(0.056)$ & $(0.55)$ \\
\hline \multirow[t]{2}{*}{ Exchange rate } & 0.615 & 0.819 & 0.565 & 0.861 \\
\hline & $(1.156)$ & $(0.005)$ & $(0.009)$ & $(0.002)$ \\
\hline \multicolumn{5}{|c|}{ Parent bank characteristics } \\
\hline \multirow[t]{2}{*}{ Size } & 5.685 & $8.66^{* * * *}$ & $-0.805 * *$ & 0.558 \\
\hline & $(0.289)$ & $(8.095)$ & $(2.566)$ & $(0.928)$ \\
\hline \multirow[t]{2}{*}{ Dep_Total_asset } & 0.556 & 0.866 & 0.858 & 0.416 \\
\hline & $(0.681)$ & $(0.565)$ & $(0.550)$ & $(0.858)$ \\
\hline \multirow[t]{2}{*}{ Loan_loss_Prov } & -0.891 & $0.989 * *$ & $0.580 * * *$ & $0.655^{*}$ \\
\hline & $(0.582)$ & $(5.856)$ & $(8.560)$ & $(.858)$ \\
\hline \multirow[t]{2}{*}{ Loan ratio } & 0.298 & 0.582 & 0.058 & 0.589 \\
\hline & $(0.988)$ & $(0.160)$ & $(0.889)$ & $(0.241)$ \\
\hline \multirow[t]{2}{*}{ ROA } & 0.991 & 0.4256 & $-0.506 * * *$ & 0.58 \\
\hline & $(0.856)$ & $(0.555)$ & $(5.68)$ & $(0.651)$ \\
\hline \multirow[t]{2}{*}{ Dep_Total_asset } & 6.809 & -5.856 & 0.886 & 5.510 \\
\hline & $(0.215)$ & $(0.68)$ & $(0.855)$ & $(0.600)$ \\
\hline \multirow[t]{2}{*}{ NIM } & 0.565 & $1.940 * * *$ & $0.550 * *$ & 0.850 \\
\hline & $(0.508)$ & $(2.840)$ & $(2.158)$ & $(0.851)$ \\
\hline \multicolumn{5}{|c|}{ Country of origin variables } \\
\hline GDP Growth & 0.249 & 0.556 & $-0.585 * * *$ & -0.885 \\
\hline & $(0.118)$ & $(0.005)$ & $(4.945)$ & $(0.865)$ \\
\hline Crisis & 0.892 & 0.586 & $0.585 * * *$ & .866 \\
\hline & $(0.586)$ & $(0.008)$ & $(6.685)$ & $(0.566)$ \\
\hline Constant & $6.528 * * *$ & $5.815 * * *$ & $5.856 * * *$ & $-8.588 * *$ \\
\hline & $(8.256)$ & $(6.686)$ & $(8.558)$ & $(5.56)$ \\
\hline R-squared & 0.3699 & 0.3865 & 0.4270 & 0.3421 \\
\hline
\end{tabular}

Note. The table reports the estimation results of $(\triangle C A R)$. The dependent variable is the change in capital adequacy ratio of foreign subsidiaries and branches. Size is the logarithm of total assets of foreign subsidiaries and parent banks. Deposits is the total deposit to total assets of subsidiary or parent bank deposits. Loans is the ratio of total loans to total assets. Loan loss provision is the ratio of loan loss provisions to net loans. ROA is the Return on Asset. NIM is the Net Interest Margin. GDP is the yearly change in GDP growth. Real interest rate is the lending interest rate adjusted for inflation as measured by the GDP deflator. Exchange rate is the exchange rate from local currency to USD. Crisis is a dummy variable that equals 1 if the year 2009 or 2008 and 0 if not. T-student statistics are reported between parentheses. $* * *, * * *$ denote significance at the $1 \%$, $5 \%$ and $10 \%$ levels, respectively. 